\title{
Analysis of Genetic Variability among Phalaenopsis Species and Hybrids Using Amplified Fragment Length Polymorphism
}

\author{
Yeun-Kyung Chang and Richard E. Veilleux \\ Department of Horticulture, Virginia Polytechnic Institute and State University, Blacksburg, \\ VA 24060 \\ Muhammad Javed Iqbal ${ }^{1}$ \\ The Institute for Sustainable and Renewable Resources (ISRR) at the Institute for Advanced Learning \\ and Research (IALR), 150 Slayton Avenue, Danville, VA 24540
}

\begin{abstract}
ADDITIONAL INDEX wORDS. moth orchid, genetic distance, coefficient of coancestry
Abstract. Phalaenopsis is the second most valuable potted plant in the United States. Information on the genetic diversity and relationships among species and hybrids is important for breeding purposes and species conservation. In this study, genetic variability of 16 Phalaenopsis species and hybrids was analyzed using amplified fragment length polymorphism (AFLP) markers. Ten AFLP primer combinations amplified 1353 DNA fragments ranging in size from 100 to 350 bp and $1285(95 \%)$ of them were polymorphic. The genetic similarity among Phalaenopsis species and hybrids ranged from 0.298 to 0.774 based on Dice coefficient. The dendrogram derived by the unweighted pair group method with arithmetic mean analysis clustered the germplasm into two main groups. Bootstrap values for the groups supported $70 \%$ of the clustering. A significant linear relationship $(r=0.724, P<0.0001)$ was observed between known pedigrees and AFLP-derived genetic similarity for 136 pairwise comparisons of Phalaenopsis species and hybrids. The results of this study demonstrate the usefulness of AFLP analysis in Phalaenopsis and its potential application in breeding and species conservation.
\end{abstract}

Orchids are not only beautiful, but also commercially important and occupy the second place in the potted flowering plant market in the United States (Griesbach, 2002). According to the U.S. Department of Agriculture (USDA) floriculture crops 2007 survey, the potted orchid industry was valued at $\$ 126$ million (USDA, 2008). Among potted orchids, Phalaenopsis comprises the majority of commercial orchids $(50 \%$ to $90 \%$ ) in the United States as a result of their long-lasting flowers, easy care, and low cost (Griesbach, 2002; Laws, 2004).

The orchid family is unique because hybridization is possible not only between species, but also between members of related genera. Moreover, hybrids can interbreed with other species to create novel combinations (Tan and Hew, 1995). As a result of these features, genetic relationships are sometimes difficult to evaluate. However, accurate information on genetic relationships among species and hybrids is needed for the conservation and use of breeding materials.

Through intensive breeding activity, 3500 Odontoglossum hybrids and intergenerics, 4300 Cattleyas hybrids and intergenerics, and over 5000 Paphiopedilum crosses had been made by 1945 (American Orchid Society, 2002). However, only $\approx 140$ Phalaenopsis hybrids were registered through 1945

Received for publication 2 Sept. 2008. Accepted for publication 14 Oct. 2008. This project was supported in part by a grant from the U.S. Department of Agriculture (USDA 2003-38891-02112), USDA HATCH funds (135816) as well as through operating funds provided by the Commonwealth of Virginia. We thank the Institute for Advanced Learning and Research (IALR) for supplying materials. We also thank Rubina Ahsan for helpful technical advice. Y.K. Chang was a graduate student at the Department of Horticulture at Virginia Tech.

The research was conducted at ISRR in MJI laboratory and coadvised by REV. ${ }^{1}$ Corresponding author. E-mail: mjiqbal@ialr.org.
(Challis, 1996). An average of 100 new Phalaenopsis hybrids was registered in the Royal Horticulture Society every 2 months from 1976 through 2008, underscoring the importance of novel Phalaenopsis hybrids for market demands.

Despite the economic importance of Phalaenopsis, the genetic potential of Phalaenopsis has not been fully exploited. An assessment of genetic variability is important for the use of genetic resources and for determining the uniqueness of genotypes to protect breeders' intellectual property rights and to exploit heterosis (Franco et al., 2001). Genetic diversity can be determined using phenotypic variation and/or molecular markers. Morphological characteristics have limitations because environmental factors and the developmental stage of the plant may influence their expression. In contrast to morphological markers, molecular markers based on DNA polymorphism are more informative, independent of environmental conditions and unlimited in number (Agarwal et al., 2008).

Several types of molecular markers are available; however, amplified fragment length polymorphism (AFLP) markers have notable advantages such as reproducibility, high levels of polymorphism that can be detected in a single reaction, genomewide distribution of markers, and no need for prior DNA sequence information compared with other DNA-based markers (Vos et al., 1995). AFLP analysis uses selective amplification of a subset of restriction enzyme-digested DNA fragments to generate a unique fingerprint of a particular genome (Mueller and Wolfenbarger, 1999). AFLP markers have been used in the assessment of genetic relationships of a wide range of species, including ornamentals such as Caladium (Loh et al., 1999), Calathea (Chao et al., 2005), Hemerocallus (Tomkins et al., 2001), Cornus (Smith et al., 2007), and 
Impatiens (Carr et al., 2003). The objectives of this study were to determine the level of genetic variability in Phalaenopsis species and hybrids using AFLP fingerprinting and to estimate the correlation of genetic relatedness with the known pedigree in various hybrids.

\section{Materials and Methods}

Plant material. Two commercially available Phalaenopsis species and 14 hybrids were used in this study (Table 1). The germplasm represents a range of flower size and colors available in the U.S. market. All the plants were maintained at 20 to $30{ }^{\circ} \mathrm{C}$ with $70 \%$ humidity in the greenhouse.

DNA extraction. Genomic DNA was extracted from fresh Phalaenopsis leaves according to Doyle and Doyle (1990) with some modifications. Plant tissue $(0.5 \mathrm{~g})$ was pulverized in liquid nitrogen and immediately transferred into a $50-\mathrm{mL}$ tube containing $10 \mathrm{~mL}$ extraction buffer [2\% CTAB, $100 \mathrm{~mm}$ Tris (pH .8.0), 1.4 M NaCl, 20 mм EDTA, 0.2\% 2-mercaptoethanol, and $4 \%$ polyvinyl pyrrolidine]. The samples were incubated at $60{ }^{\circ} \mathrm{C}$ for $1 \mathrm{~h}$ and $10 \mathrm{~mL}$ chloroform:isoamyl alcohol (24:1) was added to each sample and mixed. The samples were centrifuged at $12,000 \mathrm{~g}$ for $10 \mathrm{~min}$. The aqueous phase was transferred to a clean tube. DNA was precipitated with $5 \mathrm{~mL}$ of ice-cold isopropanol and stored at $-20{ }^{\circ} \mathrm{C}$ overnight. The samples were centrifuged at $5000 \mathrm{~g}$ for $10 \mathrm{~min}$ and the supernatant was discarded. The DNA pellet was resuspended in $20 \mathrm{~mL}$ wash buffer (10 $\mathrm{mm} \mathrm{NH}_{4} \mathrm{OAc}, 75 \%$ ethanol) for $20 \mathrm{~min}$ and centrifuged at $12,000 \mathrm{~g}$ for $5 \mathrm{~min}$. The DNA was dissolved in TE buffer $(100 \mu \mathrm{L})$ containing $100 \mu \mathrm{g}$ of RNase and incubated at $37{ }^{\circ} \mathrm{C}$ for $1 \mathrm{~h}$. DNA concentration was measured using a NanoDrop (Thermo Fisher Scientific, Waltham, MA) and quality was checked by electrophoresis on a $0.8 \%$ agarose gel in TBE buffer.

AMPLIFIED FRAGMENT LENGTH POLYMORPHISM ANALYSIS. AFLP analysis was carried out according to Vos et al. (1995) with some modifications. Genomic DNA (500 ng) was restriction-digested with EcoRI and MseI and EcoRI and MseI adapters were ligated in a final volume of $11 \mu \mathrm{L}$. The reaction contained $1 \times \mathrm{T} 4$ ligase buffer [50 mM Tris- $\mathrm{HCl}(\mathrm{pH} 7.5), 10 \mathrm{~mm}$ $\mathrm{MgCl}_{2}, 10 \mathrm{~mm}$ dithiothreitol, $1 \mathrm{~mm}$ ATP] [New England Biolabs (NEB), Ipswich, MA], $0.05 \mathrm{M} \mathrm{NaCl}, 0.045 \mathrm{mg} \cdot \mathrm{mL}^{-1}$ BSA, $1 \mu \mathrm{M}$ EcoRI adapter, $5 \mu \mathrm{M}$ MseI adapter, $5 \mathrm{U}$ EcoRI (NEB), $5 \mathrm{U}$ Mse I (NEB), and $1 \mathrm{U}$ T4 DNA ligase (NEB). The reactions were gently mixed and incubated at $37^{\circ} \mathrm{C}$ for $3 \mathrm{~h}$. After restriction and ligation, the reaction mixture was diluted 10 -fold with $0.1 \times$ TE buffer [10 mM Tris- $\mathrm{HCl}(\mathrm{pH} 8.0), 0.1 \mathrm{~mm}$ EDTA].

Preselective amplification was carried out in a final volume of $13 \mu \mathrm{L}$ consisting of $1 \times$ polymerase chain reaction $(\mathrm{PCR})$ buffer [100 mM Tris- $\mathrm{HCl}(\mathrm{pH} 8.3), 500 \mathrm{~mm} \mathrm{KCl}$, $2.0 \mathrm{~mm}$ $\mathrm{MgCl}_{2}, 0.2 \mathrm{~mm}$ dNTP, $10 \mu \mathrm{M} E c o \mathrm{RI}+\mathrm{A}$ primer, $10 \mu \mathrm{M} M s e \mathrm{I}+\mathrm{C}$ primer, and $3 \mu \mathrm{L}$ of diluted restriction-ligation product. PCR was carried out in a MyCycler thermal cycler (Bio-Rad Laboratories, Hercules, CA) programmed for $72{ }^{\circ} \mathrm{C}$ for $2 \mathrm{~min}$ followed by 20 cycles of $94^{\circ} \mathrm{C}$ for $20 \mathrm{~s}, 56{ }^{\circ} \mathrm{C}$ for $30 \mathrm{~s}$, and $72{ }^{\circ} \mathrm{C}$ for $2 \mathrm{~min}$ and a final incubation of $72{ }^{\circ} \mathrm{C}$ for $2 \mathrm{~min}$ and $60{ }^{\circ} \mathrm{C}$ for $30 \mathrm{~min}$. The preselective amplification PCR products were diluted 10 -fold in $0.1 \times \mathrm{TE}$ buffer and used as a template for selective amplification.

Selective amplification was carried out in $8 \mu \mathrm{L}$ reaction volume containing $1 \times$ PCR buffer [100 mM Tris- $\mathrm{HCl}(\mathrm{pH} \mathrm{8.3)}$,
$500 \mathrm{~mm} \mathrm{KCl}$ ], $2.0 \mathrm{~mm} \mathrm{MgCl} 2,0.2 \mathrm{~mm}$ dNTPs, $0.625 \mu \mathrm{M}$ of D4 WellRED dye-labeled EcoRI primer (E+3), $0.625 \mu \mathrm{M} \mathrm{MseI}$ primer $(\mathrm{M}+3), 0.2 \mathrm{U}$ of JumpStart Taq DNA polymerase (Sigma-Aldrich, St. Louis, MO), and $2 \mu \mathrm{L}$ of diluted preselective amplification product. The PCR amplification consisted of an initial denaturation step of $94^{\circ} \mathrm{C}$ for $2 \mathrm{~min}$ followed by the first cycle of $94{ }^{\circ} \mathrm{C}$ for $20 \mathrm{~s}, 66^{\circ} \mathrm{C}$ for $30 \mathrm{~s}, 72^{\circ} \mathrm{C}$ for $2 \mathrm{~min}$, and $1{ }^{\circ} \mathrm{C}$ decrease in annealing temperature in each of the next nine cycles. This was followed by 25 cycles of $94{ }^{\circ} \mathrm{C}$ for $30 \mathrm{~s}, 56{ }^{\circ} \mathrm{C}$ for $30 \mathrm{~s}$, and $72{ }^{\circ} \mathrm{C}$ for $3 \mathrm{~min}$. The reactions were incubated at $60{ }^{\circ} \mathrm{C}$ for $30 \mathrm{~min}$ before electrophoresis. PCR products were diluted two-fold with sample loading solution (Beckman-Coulter, Fullerton, CA) and $1.5 \mu \mathrm{L}$ of diluted reaction products were added to $40 \mu \mathrm{L}$ of sample loading solution (Beckman-Coulter). DNA size standard 600 (Beckman-Coulter) was also added to each sample. The samples were electrophoresed and detected using a Beckman-Coulter CEQ 8800 Genetic Analysis System. The Frag-4 module of CEQ was used to size all the fragments using internal DNA size standard.

DAta ANAlysis. All AFLP fragments were scored as binary data ( 1 , peak present; 0 , peak absent) along with their sizes. The binary scores were manually compared with the electropherograms to reconfirm presence or absence of peaks. NTSYS-pc software version 2.20 (Rohlf, 2005) was used to calculate the genetic distance or similarity between the samples. A cluster analysis was performed using unweighted pair group method with arithmetic mean (UPGMA) based on the Dice index (Nei and Li, 1979). This analysis was also compared using the FreeTree software package (Hampl et al., 2001). Bootstrap values (based on 1000 resamplings) were used to estimate the reliability of the clustering pattern.

Coefficients of coancestry for all possible pairs of Phalaenopsis species and hybrids were calculated according to Weir et al. (2006) based on pedigree information in the Royal Horticulture Society (RHS) orchid hybrid registration database information system (RHS, 2002). Simple linear correlation analysis was conducted to determine the association between coancestry coefficient and genetic similarity values using JMP software (version 5.1; SAS Institute, Cary, NC).

\section{Results}

A total of 1353 fragments ranging in size from 100 to $350 \mathrm{bp}$ was scored using 10 primer combinations. The number of polymorphic fragments for each primer varied from 94 (E$\mathrm{CAG} / \mathrm{M}-\mathrm{CCT})$ to 162 (E-CAG/M-CCA). The average number of polymorphic loci (DNA band/fragment) detected was 121 per primer combination. The average percentage of polymorphic loci (polymorphic loci/total loci) was $95 \%$ and the range among primer combinations was from $92 \%$ (E-CAG/M-CAG) to $97 \%$ (E-CAG/M-CCC, E-CAG/M-CAC, E-CAC/M-CCG) (Table 2). The primer combination with the lowest number of fragments (E-CAG/M-CGA) had too many ambiguous fragments for counting and was not used in the analysis.

Genetic similarities among the 16 individual Phalaenopsis species and hybrids were estimated based on the number of common fragments (Table 3). Similarity values among individual samples ranged from 0.298 to 0.774 on the Dice index. The 'Picotee' clone of Doritaenopsis Newberry Parfait (13) and Doritaenopsis (Luchia Lady $\times$ City Girl) (14) were the most closely related, whereas Phalaenopsis Sogo Little Angel (4) and Doritaenopsis Abed-Nego 'Chadwick' (15) were the most 


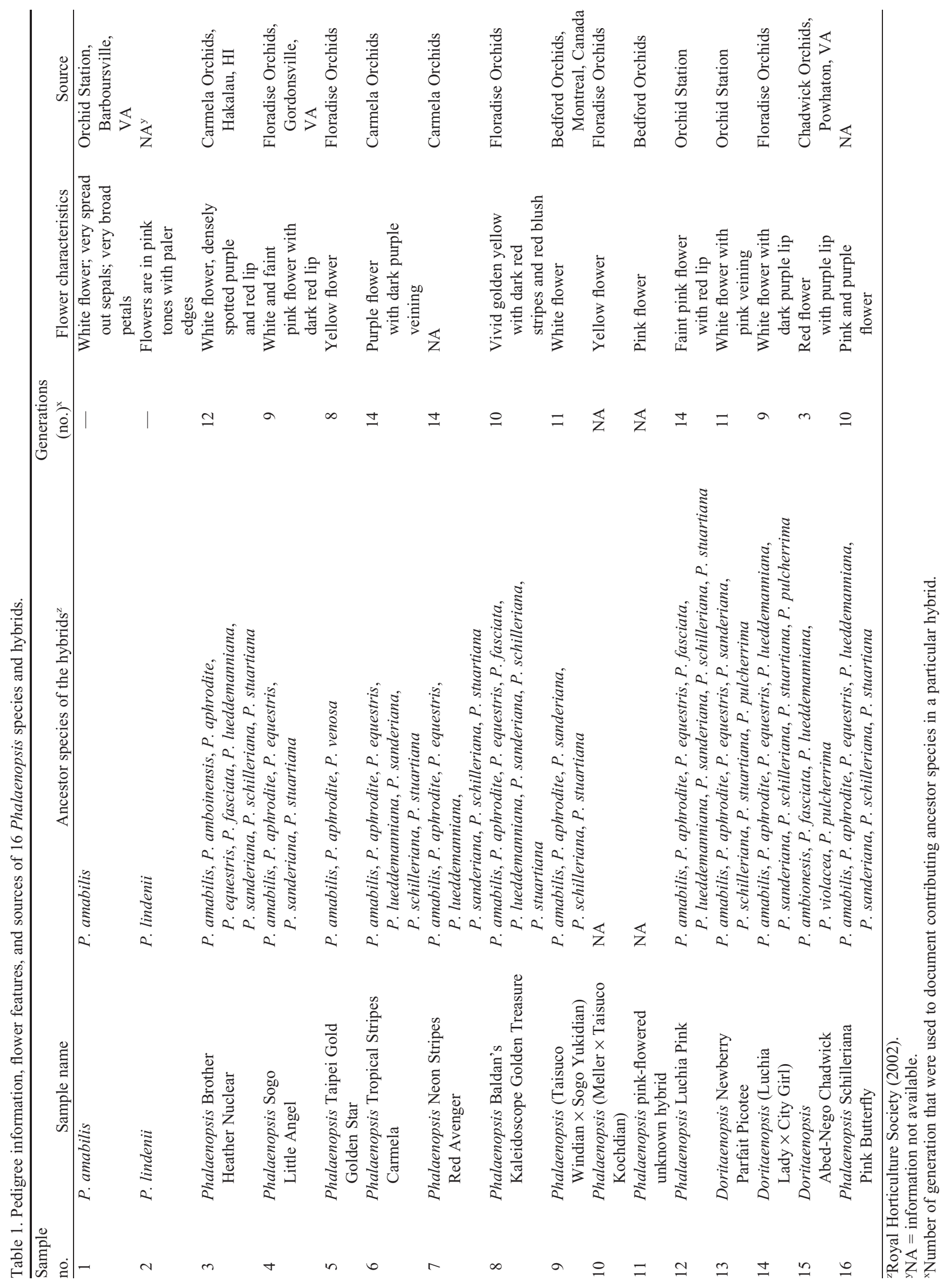


Table 2. Total number of amplified fragment length polymorphism loci examined using 10 primer combinations as well as percentage of polymorphic loci per primer combination among 16 Phalaenopsis species and hybrids.

\begin{tabular}{llccc}
\hline \multicolumn{2}{c}{$\begin{array}{c}\text { Primer } \\
\text { combination }\end{array}$} & $\begin{array}{c}\text { Loci } \\
\text { detected (no.) }\end{array}$ & $\begin{array}{c}\text { Polymorphic } \\
\text { loci (no.) }\end{array}$ & $\begin{array}{c}\text { Polymorphic } \\
\text { loci (\%) }\end{array}$ \\
\hline E-CAG & M-CCG & 143 & 136 & 95.1 \\
E-CAG & M-CCA & 169 & 162 & 95.9 \\
E-CAG & M-CCT & 100 & 94 & 94.0 \\
E-CAG & M-CCC & 139 & 135 & 97.1 \\
E-CAG & M-CGG & 131 & 123 & 93.9 \\
E-CAG & M-CGC & 162 & 151 & 93.2 \\
E-CAG & M-CGT & 136 & 128 & 94.1 \\
E-CAG & M-CAC & 108 & 105 & 97.2 \\
E-CAG & M-CAG & 129 & 119 & 92.2 \\
E-CAC & M-CCG & 136 & 132 & 97.1 \\
Total & & 1,353 & 1,285 & \\
Mean & & 135.3 & 128.5 & 95.0 \\
\hline
\end{tabular}

distantly related. Relationships among 16 Phalaenopsis species and hybrids are shown in a dendrogram using UPGMA (Fig. 1). Two groups (Group I and Group II) were obtained. Group I contains the Phalaenopsis hybrids Taipei Gold 'Golden Star', Tropical Stripes 'Carmela', Neon Stripes 'Red Avenger', and Baldan's Kaleidoscope 'Golden Treasure'. Group II was further partitioned into two subgroups (Subgroup A and Subgroup B). Subgroup A contains (Taisuco Windian $x$ Sogo Yukidian), Phalaenopsis (Meller $\times$ Taisuco Kochdian), pink-flowered unknown hybrid, and Phalaenopsis Luchia Pink. Two Doritaenopsis hybrids were closely associated in Subgroup B.

The same analysis was carried out using the FreeTree program with the Dice index and UPGMA for the comparison. Figure 2 shows the dendrogram obtained from the FreeTree program. The result was similar for Groups I and II, which contained the same two subgroups as clustering using NTSYSpc software. Bootstrap values for Group I and Group II supported $70 \%$ of the clustering. Group I containing four Phalaenopsis hybrids had bootstrap values ranging from $84 \%$ to $100 \%$. Two Doritaenopsis hybrids in Subgroup II exhibited a bootstrap value of $100 \%$. All other nodes had values greater than 64 . The plants that did not fall into obvious groups were the distinct species (Phalaenopsis amabilis and Phalaenopsis lindenii) and some of the complex hybrids with unusual parents (Phalaenopsis violacea for Doritaenopsis Abed-Nego 'Chadwick' and Phalaenopsis amboinensis for Phalaenopsis Brother Heather 'Nuclear'). The genetic contribution of these parents, unique to single entries in our study of 16 clones, may have been sufficient to differentiate them from the groups.

The range of available ancestry information of Phalaenopsis hybrids was three to 14 generations (Table 1). Therefore, coefficients of coancestry were calculated on the basis of three generations. Coefficients of coancestry based on pedigree data ranged from 0 to 0.320 with a mean of 0.100 (Table 4). From a total of 136 pairs of Phalaenopsis species and hybrids, 73 pairs did not share a common parent until the third generation. The correlation between coefficient of coancestry and AFLP-based genetic similarity was $0.724(P<0.0001)$, indicating a strong linear association between these two

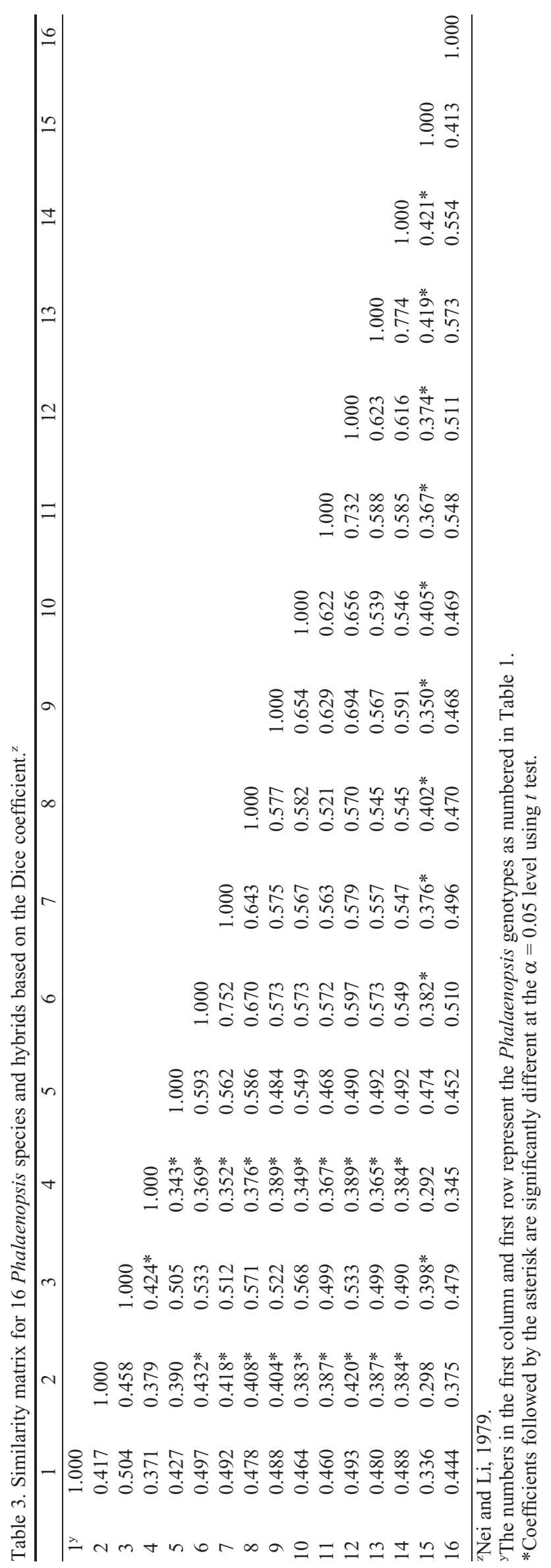




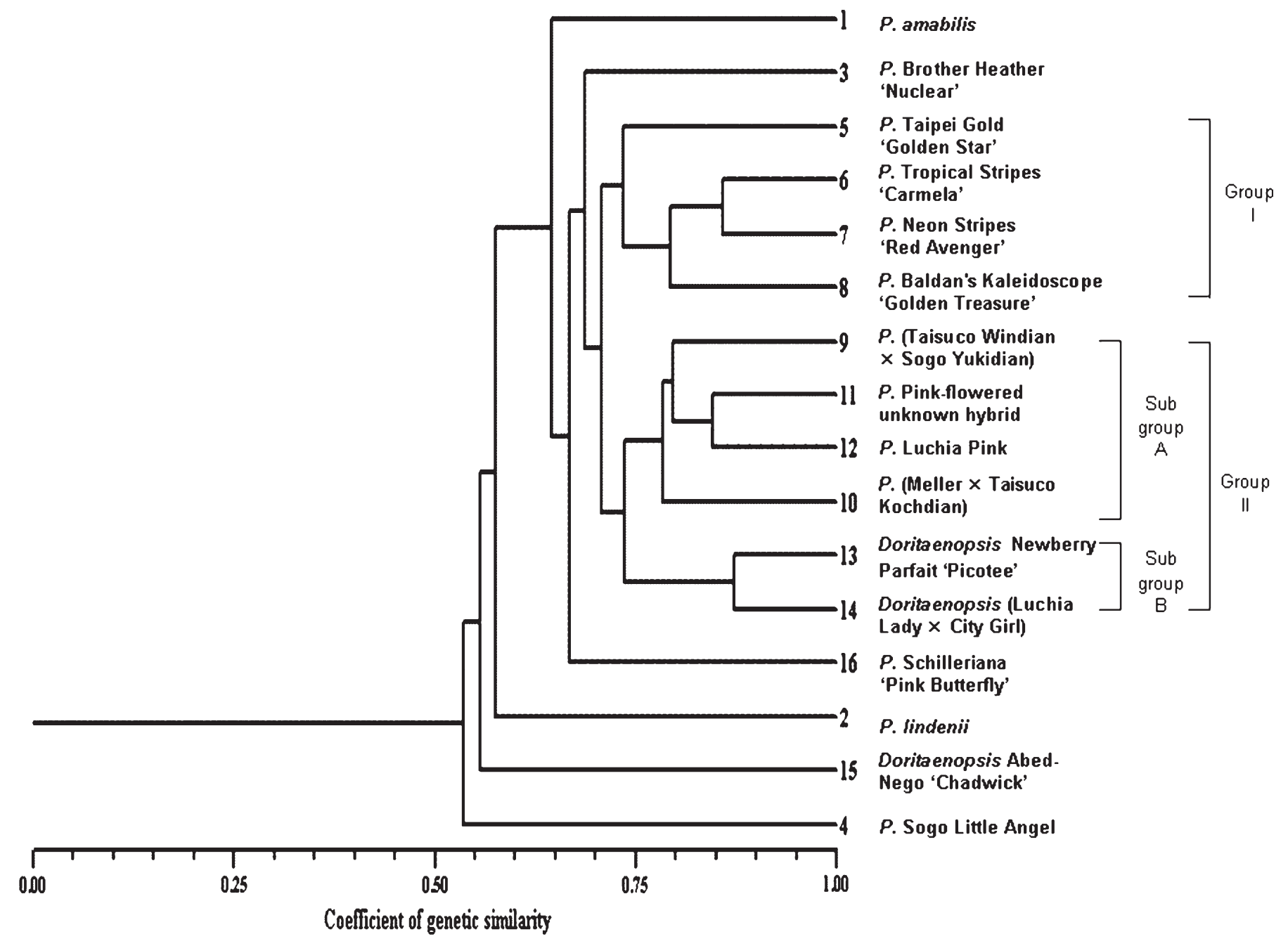

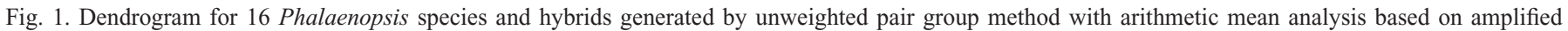
fragment length polymorphism data using the Dice coefficient of genetic similarity estimates (Nei and Li, 1979).

measures of genetic relationships within our Phalaenopsis germplasm (Fig. 3).

\section{Discussion}

In this study, 95\% of the AFLP-generated loci were polymorphic among 16 Phalaenopsis species and hybrids. This is not surprising considering the complex interspecific hybridization used to derive most modern Phalaenopsis and Doritaenopsis hybrids (Table 1). In another orchid genus, Dendrobium, $83 \%$ of the AFLP-generated loci were polymorphic among 43 hybrids (Xiang et al., 2003). In our dendrogram, P. amabilis and $P$. lindenii were distantly clustered (0.417); this is consistent with known pedigrees of Phalaenopsis based on random amplified polymorphic DNA (RAPD) markers. P. amabilis can be found within the pedigrees of nearly all Phalaenopsis cultivars, whereas $P$. lindenii has not been used frequently in Phalaenopsis hybrid breeding and the dendrograms reflect these relationships. Traditionally, $P$. amabilis and $P$. lindenii were classified in separate sections, Phalaenopsis and Stauroglottis, respectively, within the subgenus Phalaenopsis (Christenson, 2001). Fu et al. (1997) reported that P. amabilis, section Phalaenopsis, was taxonomically close to Phalaenopsis equestris, section Stauroglottis using RAPD markers. P. amabilis and $P$. equestris exhibited a genetic similarity of 0.339 in their study. Thus, the genetic similarity of 0.417 between $P$. amabilis and $P$. lindenii in our study is close to the previous RAPD analysis result (Fu et al., 1997). Furthermore, based on other molecular data analyses, clustering between P. amabilis and P. lindenii was supported as well. Goh et al. (2005) assembled 46 species of Phalaenopsis into seven main groups based on RAPD analysis and reported that $P$. amabilis and $P$. lindenii occurred in the same group but belonged to two different sections, Phalaenopsis and Stauroglottis, respectively. In other examples, $P$. amabilis and $P$. lindenii were treated as different members using the internal transcribed Spacers 1 and 2 of nuclear ribosomal DNA (Tsai et al., 2003, 2006) and DNA sequences of the plastid genome ( $m a t K$ and $t r n K$ introns) and the nuclear genome (Yukawa et al., 2005).

The relatively high bootstrap values $(70 \%)$ support two major clades in Phalaenopsis hybrids used in this study (Fig. 2). Phalaenopsis hybrids Taipei Gold 'Golden Star', Tropical Stripes 'Carmela', Neon Stripes 'Red Avenger', and Baldan's Kaleidoscope 'Golden Treasure' were placed in Group I with $84 \%$ bootstrap value. In this study, we had five hybrids $(1,3,4$, 


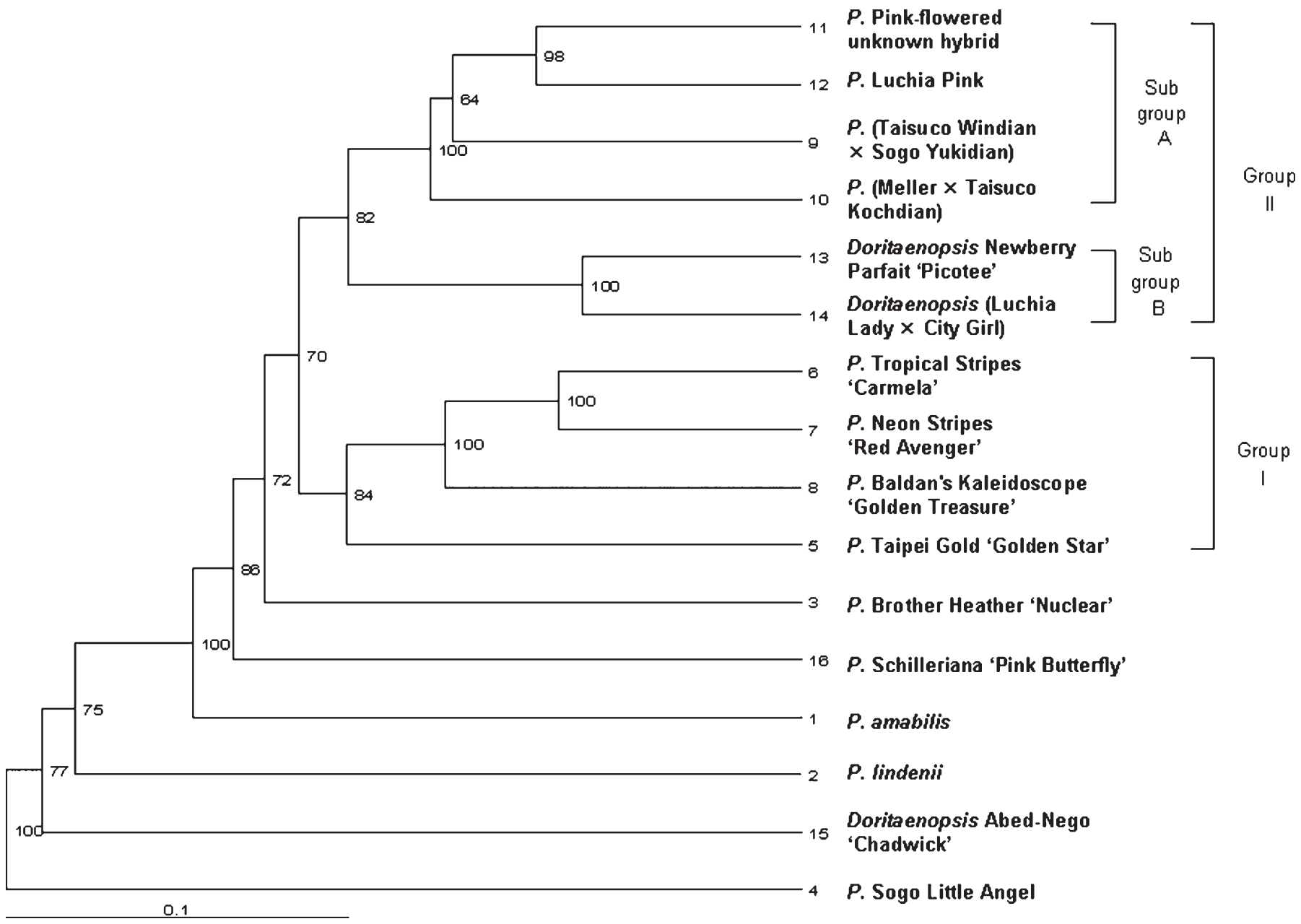

Fig. 2. Genetic relationships of 16 Phalaenopsis species and hybrids based on amplified fragment length polymorphism data. Dendrogram was generated using FreeTree program (Hampl et al., 2001), the Dice index and unweighted pair group method with arithmetic mean analysis. Numbers on the branches are bootstrap values and range from $64 \%$ to $100 \%$.

13 , and 14) with white flowers, four $(2,11,12$, and 16) with pink flowers, and three $(5,8$, and 10$)$ with yellow flowers. The dendrograms revealed that a simple classification based on only flower color would not have accurately reflected genetic relatedness.

Phalaenopsis hybrids classified by AFLP clustering were found to be consistent with known pedigrees. Group I and Group II on the dendrogram cluster several complex Phalaenopsis hybrids together. Genetic relationship derived from our AFLP analysis was verified in the RHS orchid hybrid registration database information system (RHS, 2002). The RHS parentage records reveal that clustered hybrids shared common ancestry. For example, Taipei Gold 'Golden Star', Tropical Stripes 'Carmela', Neon Stripes 'Red Avenger', and Baldan's Kaleidoscope 'Golden Treasure' are placed in Group I. These hybrids shared $P$. amabilis and Phalaenopsis aphrodite as common ancestors (Table 1). Tropical Stripes 'Carmela' clustered closely to Neon Stripes 'Red Avenger' at genetic distance 0.752 in Group I. These hybrids shared seven common parents: P. amabilis, P. aphrodite, P. equestris, Phalaenopsis lueddemanniana, Phalaenopsis sanderiana, Phalaenopsis schilleriana, and Phalaenopsis stuartiana. Thus, Tropical Stripes 'Carmela' is genetically close to Neon Stripes 'Red Avenger' and this fact was confirmed by our AFLP analysis.
The 'Picotee' clone of Doritaenopsis Newberry Parfait clustered close to Doritaenopsis (Luchia Lady $\times$ City Girl) in Group II; and both had $P$. amabilis, $P$. aphrodite, $P$. equestris, $P$. sanderiana, $P$. schilleriana, $P$. stuartiana, and Phalaenopsis pulcherrima as common parents. Our pink-flowered unknown hybrid clustered with Phalaenopsis Luchia Pink at genetic distance 0.732 . Although the information for the pink-flowered unknown hybrid was unavailable as a result of a lost tag during shipping, the close relationship between it and Phalaenopsis Luchia Pink indicates their common parentage. The complex origin of Phalaenopsis hybrids ensures considerable polymorphism even when individuals share several common parents, revealing AFLP as a powerful tool for DNA fingerprinting in this valuable crop.

From the dendrogram, AFLP data placed Sogo Little Angel (4) and Schilleriana 'Pink Butterfly' (16) as outliers of Groups I and II despite their shared common ancestry and more distant from P. amabilis than either group. P. amabilis was found in the ancestry of 11 of the entries, the only exclusions being $P$. lindenii (2) and Doritaenopsis Abed-Nego 'Chadwick' (15) which logically occurred as outliers. The greater genetic distance of Sogo Little Angel (4) and Schilleriana 'Pink Butterfly' (16) from P. amabilis and the other hybrids may be the result of uneven gene flow and nuclear distribution of the 


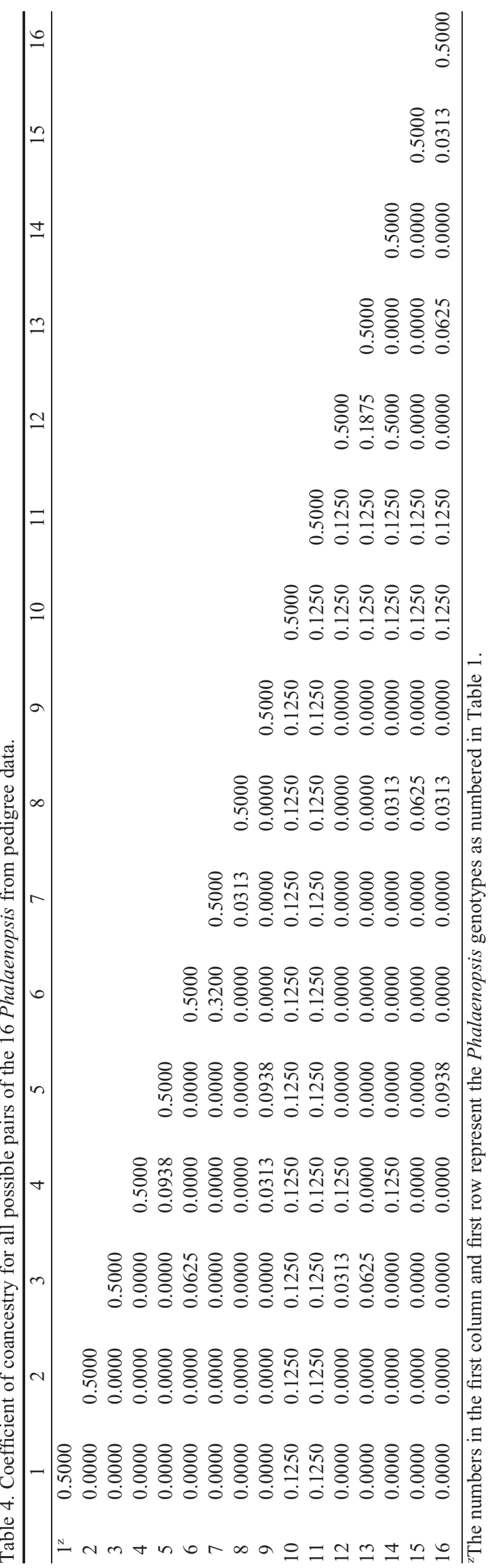

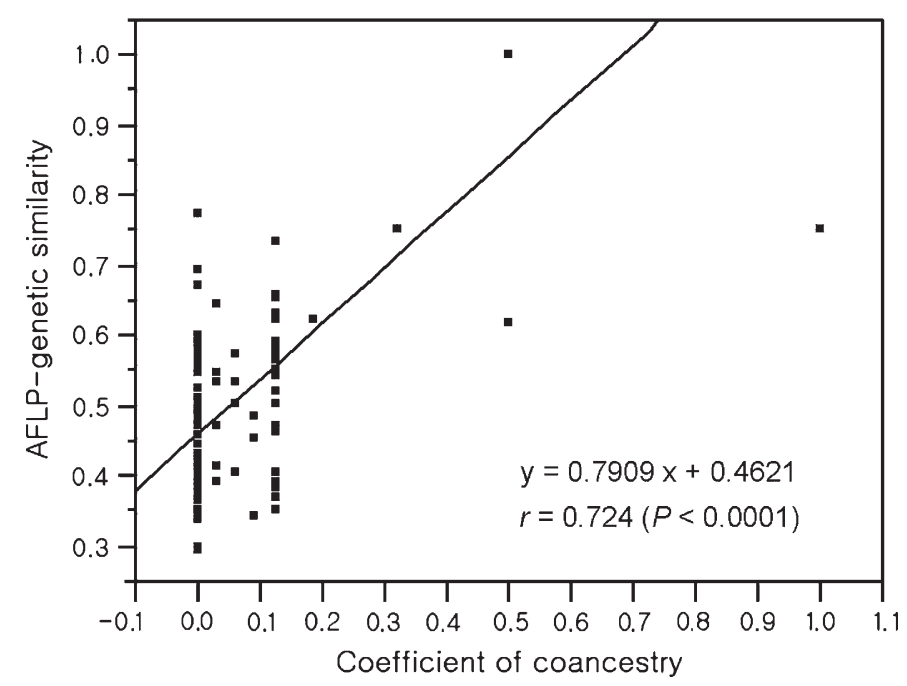

Fig. 3. Plot of amplified fragment length polymorphism-based genetic similarity coefficient (Nei and Li, 1979 ) and coefficient of coancestry for 136 pairs of Phalaenopsis species and hybrids.

interspecific hybrids (Lexer et al., 2006). Although P. amabilis has shared alleles with other species such as $P$. aphrodite, $P$. equestris, $P$. lueddemanniana, $P$. sanderiana, $P$. schilleriana, and $P$. stuartiana, it is possible that the genomes of Sogo Little Angel and Schilleriana 'Pink Butterfly' comprise a different subset of the genomes of other species found in their parentage. Another possibility for Little Angel (4) and Schilleriana 'Pink Butterfly' (16) occurring as outliers is that these hybrids may represent somaclones derived from tissue culture during cultivar development. Tissue culture has been widely used for mass propagation in Phalaenopsis (Tokuhara and Mii, 1993). Somaclonal variants with altered phenotypes have been reported to occur in a range of $0 \%$ to $14 \%$ (Tokuhara and Mii, 1998, 2001). Somaclonal variation at the molecular level has been documented in Phalaenopsis using RAPD (Chen et al., 1998), cDNARAPD (Chen et al., 2005), and cDNA-AFLP (Hsu et al., 2008). Genetic polymorphism associated with the somaclones, some of which demonstrated remarkable phenotypic variation as well as differential gene expression have been identified. Hsu et al. (2008) found slightly more than $1 \%$ distinct sequences in somaclones among 2269 transcript-derived fragments.

The correlation tests revealed that the AFLP-derived genetic similarity values showed a statistically significant correlation with the coefficient of coancestry values based on known pedigree data (Fig. 3). In Austrian wheat, close associations between coefficient of parentage and RFLP-based genetic similarity $(r=0.535)$ and between coefficient of parentage and simple sequence repeat-based genetic similarity $(r=0.633)$ were reported (Parker et al., 2002). In European maize inbred lines, a highly significant relationship ( $r=0.71$ and 0.86$)$ was reported between coefficient of parentage and RFLP-based genetic similarity (Messmer et al., 1993). Therefore, both the coefficient of coancestry based on pedigree data and DNA marker-based estimates of genetic similarity provided similar information about the genetic relationships among germplasm.

The taxonomy of Phalaenopsis is complex. Intensive breeding over many years has generated numerous commercial hybrids. Two of the most important hybrids, Phalaenopsis Gilles Gratiot $(P$. aphrodite $\times P$. rimestadiana) and Phalaenopsis Elisabethae $(P$. amabilis $\times P$. rimestadiana $)$, were 
developed in 1920 and led to a major advance in Phalaenopsis breeding (Griesbach, 2002). Most of our 14 Phalaenopsis hybrids were also derived from Phalaenopsis Gilles Gratiot and Phalaenopsis Elisabethae. Commercial Phalaenopsis hybrids were developed through both inbreeding and outcrossing, leading to high rates $(95 \%)$ of polymorphism detected in our AFLP analysis.

Previous Phalaenopsis genome studies (Kao et al., 2001; Lin et al., 2005) also provide information about genetic variation through species relationship. Arends (1970) separated Phalaenopsis into large and small chromosome groups. Phalaenopsis species with large chromosomes include $P$. amboinensis and $P$. pulcherrima. Phalaenopsis species with small chromosomes include $P$. amabilis, $P$. aphrodite, $P$. equestris, $P$. sanderiana, $P$. lueddemanniana, and $P$. stuartiana. High frequencies of bivalents were reported in hybrids between species with large chromosomes (e.g., $P$. amboinensis $\times P$. pulcherrima) and between species both with small chromosomes (e.g., $P$. amabilis $\times P$. lueddemanniana). Kao et al. (2001) suggested that chromosome size was associated with repetitive genomic DNA content and mixed genome size through inbreeding and outcrossing may have led to the diversity found in Phalaenopsis (Flavell, 1982).

This is the first study of genetic variability among Phalaenopsis species and hybrids based on AFLP analysis. Analyzing AFLP among Phalaenopsis species and hybrids demonstrated significant genetic diversity. Assessments of genetic variation and relationships using both the known pedigree data and genetic fingerprinting will be useful in orchid breeding. This will allow breeders to select appropriate parents based on their genetic distance in addition to the morphological traits for future breeding. Because of all of the other factors to be considered in parent selection, e.g., chromosome number and size, phenotypic traits, species composition, and ploidy, the influence of genetic distance on performance of hybrids (hybrid vigor) may not be obvious. The genetic variability at the DNA level identified by markers such as AFLP will also be useful in species and variety conservation by identifying core collections for preservation in orchid germplasm banks and breeders' proprietary rights.

\section{Literature Cited}

Agarwal, M., N. Shrivastava, and H. Padh. 2008. Advances in molecular marker techniques and their applications in plant sciences. Plant Cell Rpt. 27:617-631.

American Orchid Society. 2002. Orchid source directory. Amer. Orchid Soc., Delray Beach, FL.

Arends, J.C. 1970. Cytological observations on genome homology in eight interspecific hybrids of Phalaenopsis. Genetica 41:88-100.

Carr, J., M. Xu, J.W. Dudley, and S.S. Korban. 2003. AFLP analysis of genetic variability in new guinea impatiens. Theor. Appl. Genet. 106:1509-1516.

Challis, A. 1996. Phalaenopsis hybridizing: An overview. Nwsl. Ann Arbor Orchid Soc., Ann Arbor, MI.

Chao, C.C.T., P.S. Devanand, and J.J. Chen. 2005. AFLP analysis of genetic relationships among Calathea species and cultivars. Plant Sci. 168:1459-1469.

Chen, W.H., T.M. Chen, Y.M. Fu, R.M. Hsieh, and W.S. Chen. 1998. Studies on somaclonal variation in Phalaenopsis. Plant Cell Rpt. 18: $7-13$.

Chen, Y.H., Y.J. Tsai, J.Z. Huang, and F.C. Chen. 2005. Transcription analysis of peloric mutants of Phalaenopsis orchids derived from tissue culture. Cell Res. 15:639-657.
Christenson, E.A. 2001. Phalaenopsis. Timber Press, Portland, OR. Doyle, J.J. and J.L. Doyle. 1990. Isolation of plant DNA from fresh tissue. Focus 12:13-15.

Flavell, R.B. 1982. Sequence amplification, deletion and rearrangement: Major sources of variation during species divergence, p. 301323. In: Dover, G.A. and R.B. Flavell (eds.). Genome evolution. Academic Press, London, UK.

Franco, J., J. Crossa, J.M. Ribaut, J. Betran, M.L. Warburton, and M. Khairallah. 2001. A method for combining molecular markers and phenotypic attributes for classifying plant genotypes. Theor. Appl. Genet. 103:944-952.

Fu, Y.M., W.H. Chen, W.T. Tsai, Y.S. Lin, M.S. Chyou, and Y.H. Chen. 1997. Phylogenetic studies of taxonomy and evolution among wild species of Phalaenopsis by random amplified polymorphic DNA markers. Rpt. Taiwan Sugar Res. Inst. 157:27-42.

Goh, M.W.K., P.P. Kumar, S.H. Lim, and H.T.W. Tan. 2005. Random amplified polymorphic DNA analysis of the moth orchids, Phalaenopsis (Epidendroideae:Orchidaceae). Euphytica 141:11-22.

Griesbach, R.J. 2002. Development of Phalaenopsis orchids for the mass-market, p. 458-465. In: Janick, J. and Whipkey (eds.). Trends in new crops and new uses. ASHS Press, Alexandria, VA.

Hampl, V., A. Pavlicek, and J. Flegr. 2001. Construction and bootstrap analysis of DNA fingerprinting-based phylogenetic trees with the freeware program FreeTree: Application to trichomonad parasites. Int. J. Syst. Evol. Microbiol. 51:731-735.

Hsu, T.W., W.C. Tsai, D.P. Wang, S. Lin, Y.Y. Hsiao, W.H. Chen, and H.H. Chen. 2008. Differential gene expression analysis by cDNAAFLP between flower buds of Phalaenopsis Hsiang Fei cv. H. F. and its somaclonal variant. Plant Sci. 175:415-422.

Kao, Y.Y., S.B. Chang, T.Y. Lin, C.H. Hsieh, Y.H. Chen, W.H. Chen, and C.C. Chen. 2001. Differential accumulation of heterochromatin as a cause for karyotype variation in Phalaenopsis orchids. Ann. Bot. (Lond.) 87:387-395.

Laws, N. 2004. The world's fascination with potted orchids. Floriculture Intl. 14:26-27.

Lexer, C., A. Kremer, and R.J. Petit. 2006. Shared alleles in sympatric oaks: Recurrent gene flow is a more parsimonious explanation than ancestral polymorphism. Mol. Ecol. 15:2007-2012.

Lin, C.C., Y.H. Chen, W.H. Chen, C.C. Chen, and Y.Y. Kao. 2005. Genome organization and relationships of Phaldenopsis orchids inferred from genomic in situ hybridization. Bot. Bul. Acad. Sinica 46:339-345.

Loh, J.P., R. Kiew, A. Kee, L.H. Gan, and Y.Y. Gan. 1999. Amplified fragment length polymorphism (AFLP) provides molecular markers for the identification of Caladium bicolor cultivars. Ann. Bot. (Lond.) 84:155-161.

Messmer, M.M., A.E. Melchinger, R.G. Herrmann, and J. Boppenmaier. 1993. Relationships among early European maize inbreds: II. Comparison of pedigree and RFLP data. Crop Sci. 33:944-950.

Mueller, U.G. and L.L. Wolfenbarger. 1999. AFLP genotyping and fingerprinting. Trends Ecol. Evol. 14:389-394.

Nei, M. and W.H. Li. 1979. Mathematical model for studying genetic variation in terms of restriction endonucleases. Proc. Natl. Acad. Sci. USA 76:5269-5273.

Parker, G.D., P.N. Fox, P. Langridge, K. Chalmers, B. Whan, and P.F. Ganter. 2002. Genetic diversity within Australian wheat breeding programs based on molecular and pedigree data. Euphytica 124:293306.

Rohlf, F.J. 2005. NTSYS-pc numerical taxonomy and multivariate analysis system. Version 2.20. Exeter Software, Setauket, NY.

Royal Horticultural Society. 2002. Royal Horticultural Society orchid hybrid registration database information system. 4 May 2008. $<$ http://www.rhs.org.uk/plants/registerpages/orchidsearch.asp/>.

Smith, N.R., R.N. Trigiano, M.T. Windham, K.H. Lamour, L.S. Finley, X.W. Wang, and T.A. Rinehart. 2007. AFLP markers identify Cornus florida cultivars and lines. J. Amer. Soc. Hort. Sci. 132:90-96. Tan, H.T.W. and C.S. Hew. 1995. A guide of orchids of Singapore. Singapore Science Center, Singapore. 
Tokuhara, K. and M. Mii. 1993. Micropropagation of Phalaenopsis and Doritaenopsis by culturing shoot tips of flower stalk buds. Plant Cell Rpt. 13:7-11.

Tokuhara, K. and M. Mii. 1998. Somaclonal variation in flower and inflorescence in micropropagated plants through flower stalk bud of Phalaenopsis and Doritaenopsis axis culture. Plant Biotechnol. 15:23-28.

Tokuhara, K. and M. Mii. 2001. Induction of embryogenic callus and cell suspension culture from shoot tips excised from flower stalk buds of Phalaenopsis (Orchidaceae). In Vitro Cell Dev. Biol. Plant 37:457-461.

Tomkins, J.P., T.C. Wood, L.S. Barnes, A. Westman, and R.A. Wing. 2001. Evaluation of genetic variation in the daylily (Hemerocallis spp.) using AFLP markers. Theor. Appl. Genet. 102:489-496.

Tsai, C.C., S.C. Huang, and C.H. Chou. 2006. Molecular phylogeny of Phalaenopsis Blume (Orchidaceae) based on the internal transcribed spacer of the nuclear ribosomal DNA. Plant Syst. Evol. 256:1-16.

Tsai, C.C., S.C. Huang, P.L. Huang, and C.H. Chou. 2003. Phylogeny of the genus Phalaenopsis (Orchidaceae) with emphasis on the subgenus
Phalaenopsis based on the sequences of the internal transcribed spacers 1 and 2 of rDNA. J. Hort. Sci. Biotechnol. 78:879-887.

U.S. Department of Agriculture. 2008. Floriculture crops 2007 summary. U.S. Dept. Agr., Agr. Stat. Board, Washington, DC.

Vos, P., R. Hogers, M. Bleeker, M. Reijans, T. Vandelee, M. Hornes, A. Frijters, J. Pot, J. Peleman, M. Kuiper, and M. Zabeau. 1995. AFLP: A new technique for DNA fingerprinting. Nucleic Acids Res. 23:4407-4414.

Weir, B.S., A.D. Anderson, and A.B. Hepler. 2006. Genetic relatedness analysis: Modern data and new challenges. Nat. Rev. Genet. 7:771-780.

Xiang, N., Y. Hong, and L.T. Lam-Chan. 2003. Genetic analysis of tropical orchid hybrids (Dendrobium) with fluorescence amplified fragment length polymorphism (AFLP). J. Amer. Soc. Hort. Sci. 128:731-735.

Yukawa, T., K. Kita, T. Handa, T. Hidayat, and M. Ito. 2005. Molecular phylogenetics of Phalaenopsis (Orchidaceae) and allied genera: Re-evaluation of generic concepts. Acta Phytotaxonomica Geobotanica 56:141-161. 